\title{
Survival Strategy of Creative Industrial Enterprises Jombang District Perspective Inheritance Economic Activities
}

\author{
Cahyo Tri Atmojo ${ }^{*}$, Munawaroh Munawaroh ${ }^{2}$, Fahimul Amri ${ }^{3}$ \\ 1,2,3 STKIP PGRI Jombang, Indonesia \\ ${ }^{*}$ Corresponding author. Email: cahyotriatmojo@gmail.com
}

\begin{abstract}
The creative industry existence has some significant impact on unemployment amount.One creative industry is beads, or manik-manik, in plumbon gambang Gudo District, Jombang Regency. It started in the 1988s and is still surviving by maintaining local wisdom in economic activities, especially production activities. Therefore, researchers are interested in conducting a study on the survival strategy of creative industry entrepreneurs in Jombang district from the perspective of economic activity inheritance. The research objective is to reveal how the inheritance of the creative industry entrepreneur's economic activities in Jombang district concerning production and distribution in the technological era. The approach used in this research is a qualitative approach with data collection methods, among others: interviews and documentation. This research found that in the creative industry of beads in Plumbon Gambang Village, Gudo District, Jombang Regency, the pattern of inheritance of production activities, the entrepreneurs carry out the pattern of inheritance production activities by continuing to use traditional equipment and avoiding technological advances in production. The use of traditional equipment is intended to maintain the authenticity of the texture and quality of the beads produced. Entrepreneurs use three distribution systems in the distribution aspect, including direct distribution, semi-direct distribution, and indirect distribution.
\end{abstract}

\section{Keywords: Survival Strategy, Creative Industry, Inheritance of Economic Activities}

\section{INTRODUCTION}

The global economy era is a big challenge for every business. The openness of economic activities during the global economy has positive and negative impacts on creative industry entrepreneurs in a country. The economic globalization would open up competitively market opportunities for domestic and international products [1]. However, on the other hand, it also opens opportunities for global products to enter the domestic market. The existence of trade competition between domestic products and foreign products as well as strategies in marketing is a challenge for the creative economy industry entrepreneurs. The positive side that they can do is that through the era of the ASEAN Economic Community, they have the opportunity to develop product marketing to all ASEAN countries, and vice versa. But there is also a negative side related to technological readiness in the business sector that supports production, marketing, and sales activities. Global economic activity has been tested through the era of the ASEAN Economic Community. The ASEAN Economic Community is a moment to test the prowess of companies in Indonesia before facing global competition in 2020 [2]. This moment is a "life and death battle" for every company in Indonesia, regardless of their business. Revealed that economic globalization is a process of global economic activity involving countries in the world [3]. With the existence of free trade in the current era of economic globalization, Micro, Small and Medium Enterprises (MSMEs) are required to carry out the right strategies to win the competition. According, the globalization is a multidimensional concept because it covers many fields, such as the economic, political, and social [4]. Revealed that globalization has changed the world and companies' competitive situation and has affected us as individuals [5].

Indonesia is one part of ASEAN countries that also cannot be separated from the global economic era. The economic potential in each region creates challenges in 
making decisions to survive and be sustainable. With the global economy, MSMEs in Indonesia will participate in the competition for enterprises sustainability to continue to open up job opportunities for the unemployed.

Enterprises sustainability has a significant role in improving the economic conditions of the community. The emergence of micro, small and medium enterprises will have a direct impact on the absorption of unemployment. This condition also occurs in Jombang district, which contributes to the development of MSMEs in Indonesia. An MSME has successfully developed to all corners of a village in this area. Most households in this village have it with the same commodity that has been carried out for generations. The enterprise, which has developed and passed on to almost every household in this village, is beaded or manik-manik industry. Beads are a kind of accessory for the general public and are pieces of jewellery or symbols for some indigenous peoples in some tribes in Indonesia. The beads industry is a hallmark of Jombang district. It is initiated by two people in the 1988's. Until now, the community still maintains traditional ways of production and has grown in every household. That is the uniqueness of the MSME beads as a handicraft industry

Based on these phenomena, it is essential to examine the creative industry enterprises sustainability strategy in Jombang from the perspective of the inheritance of economic activities. The findings of this study will be meaningful information and have implications for the construction of the creation of small enterprises entities to empower local economic potential further.

\section{LITERARUTE REVIEW}

\subsection{Inheritance of Local Economic Potential}

Inheritance is something that cannot be avoided in the times. Inheritance can be formed. On the other hand, it can also be formed naturally by itself according to individual interests. A child will imitate what his/her parents do, and parents can shape the child according to what he/she wants. Inheritance can be said to be a process in creating a new generation by inheriting the characteristics that already exist and have been carried out by the previous generation. Inheritance is a movable or immovable object that has been given by the heirs [6]. The elements of inheritance are heirs, inheritance, the transition process, the rule of law, and society. In the current era of globalization with various modernization attacks, it is very important to maintain culture. The importance of inheritance in an area can be carried out by the community and the government.

In terms of local economic potential, there are several economic activities that cannot be replaced by technology. It means that there are economic activities in the form of production and distribution that do not entirely depend on technological developments. The use of technology will be beneficial in several fields of economic activity. The potential of the local economy that does not entirely depend on technological progress is from the handicraft sector with an artistic basis.

Regarding the situation, Jombang has a form of cultural inheritance in the form of works of art. The works of art found in Jombang Regency are beads. Beaded art is a kind of accessory for the general public and is a symbol or ornament for some indigenous peoples in some tribes in Indonesia. The production of beads from these industrial centres has been known by several countries such as Malaysia, Japan, Timor-Timor, the Netherlands, Germany, France, and several countries in the African continent. While domestically, it is well known in Bali, Kalimantan, and East Nusa Tenggara. These beaded artworks have been created since 1970 and have grown in almost every household in Gambang Village, Jombang Regency. This work of art has been done by several generations and has left an economic activity in the form of production patterns and distribution patterns.

\section{METHOD}

The approach used in this study is a qualitative approach. Through a qualitative approach, the researchers can reveal the pattern of inheritance of production activities in terms of the economic considerations of entrepreneurs regarding the use of traditional tools. Further, the researcher can also reveal how to inherit the pattern of production activities, including the production process and calculating production costs. Additionally, the pattern of inheritance of distribution activities in terms of distribution channels and how to inherit the pattern of activities distribution in terms of calculating distribution costs. The research process is carried out to obtain data by conducting field observations, interviews. The data analysis process is carried out by reducing the data obtained based on interviews, presenting the data, and drawing conclusions. After data analysis, the last step is verifying the data. In obtaining accurate results, the researchers check the validity of the research data using source triangulation to prove the suitability of the data obtained from the informants. 


\section{RESULT}

\subsection{Findings of the Study \\ 1.Inheritance of the pattern of production activities in terms of the entrepreneur's economic considerations regarding the use of traditional tools}

In meeting the needs and desires of the community, economic activity is the key to the fulfilment of needs and desires. Production activities are needed to achieve prosperity. Beads can be a secondary need for its fans. Producing beads is a unique activity because it uses traditional equipment, and no one uses modern equipment. The bead production system has been carried out from generation to generation since the 1970s and developed in 1988. The biggest challenge in maintaining local economic potential is how to keep the inheritance of production and distribution of the pioneers from being lost so that the business or local economic potential in the form of beads persists. The problem also comes from the limited skilled workforce. Skill regeneration is essential, but job competition as workers in large factories look tempting while the number of craftsmen who have the skills to make rolled glass beads decreases. The production inheritance system in Plumbong Gambang Village is started from parents and then passed down to children and relatives.

\section{Inheritance of the pattern of production activities in terms of calculating production costs}

In supporting the success of enterprises, ideally, every entrepreneur should use a standard financial system of accounting. Calculation of production costs must be carried out properly so that entrepreneurs will not experience difficulties carrying out business sustainability in terms of business financing. It has also been applied to the bead craftsmen in Plumbon Gambang Village. The production calculation they have done included the cost of purchasing materials, equipment, and labour. However, they did not use professional accounting calculations. The craftsmen tend to do calculations that include material expenditure, equipment shopping, and labour which becomes production costs that determine the price of the beads.

The inheritance of the pattern of production activities in calculating production costs from bead craftsmen does not use the company's standard accounting system. In calculating costs, they only perform standard calculations through a memorandum of purchase of materials, then increase workers' wages. In practice, what craftsmen do is only limited to production costs to determine the selling price.

\section{Inheritance of the pattern of Distribution activities}

The inheritance of the pattern of distribution activities in terms of distribution channels carried out by bead craftsmen in Plumbon Gambang Village is in the form of direct channels through shops or consumers who come to the production site. Craftsmen also use other distribution channels through retailers in several areas.

In beads MSMEs, craftsmen do not use the standard formula in determining distribution costs. They prefer to use a simple pattern by considering shipping costs or delivery services if they distribute them outside the area. In this kind of situation, the craftsmen will follow the costs of the delivery service. If they send the products personally, the craftsmen will consider the delivery service costs and the transportation.

\section{DISCUSSION}

The findings of the study reveal that local economic potential is an important thing to be developed in each region. Its development cannot be separated from the production and distribution activities in winning the market competition. A good production activity will result in good product quality as well. The quality of the production process and optimization of production costs are the keys to success in the competition. It is in line, who convey that the quality of production and the speed are the keys to winning the competition [7]. Other than argue that the road to success is a gradual path to optimizing the production process and reducing the production costs [8]. The things mentioned above have been done by beads MSMEs, the creative economy industry in Jombang. In their development, these MSMEs have taken into account the quality of production. The craftsmen traditionally carry out the production activities without using modern equipment that utilizes advanced technology. It is done because there needs to be a level of detail in the process of making beads. The beads production process is not only to pay attention to the shape of the beads produced but also to the level of art and the characteristics of the region as a whole. The number of beaded competitors from outside threatens the sustainability of their business. Based on the information obtained from the interview, competitors are from outside Indonesia who sell their products at very low prices. However, with this kind of situation, the craftsmen still stick to the traditional equipment and production processes. The use of traditional tools that have become a habit indeed can make the working system more effective. The effectiveness of production activities will further minimize the risk to make the production costs more effective and efficient. It supports opinion that effective tools are used to improve the performance of the production system at various levels of its operation [9]. 
This kind of situation makes the beads in Jombang well known and in demand by customers in Indonesia and outside Indonesia. The customers appreciate the high level of art and the good quality.

In fulfilling both domestic and foreign customers' requests, beads craftsmen realize that the distribution process is very important in providing a high level of customer satisfaction. Other than argues that distribution is an important part of running a business, both large and small businesses [10]. The company's decision to determine the distribution strategy and distribution channel that will be carried out determines the smooth distribution process to provide benefits for the company and those in the distribution channel. The distribution activities of the products carried out by the bead craftsmen are currently more through local shops located in tourist areas. Determining the purpose of product distribution through planning will make the products to be sold have a great opportunity to be demanded and purchased by customers so that sales volume will also increase. Argue that distribution channels have a close relationship with sales volume. Maximum distribution channels from product providers will increase sales volume. Distribution channels provide an impetus to customers to establish a strong relationship with the company [11]. Appropriate and consistent distribution will be able to build a better level of consumer loyalty. Place selection is very important in product distribution channels. Stated that the location selection decision is related to a long-term commitment to aspects that are capital intensive [12]

\section{CONCLUSION}

\subsection{Conclusion}

\section{Inheritance of the pattern of production activities in terms of the production process}

According to the results of the study, the inheritance in production activities in the beads MSMEs in Plumbon Gambang Village, Gudo District, Jombang Regency is done by providing training, from the pioneers to children and relatives, in the use of tools and selection of production materials. In the production activities, the materials and traditional tools used remain the same.

\section{Inheritance of the pattern of production activities in terms of calculating production costs}

In calculating the production cost, the inheritance pattern was done by emphasising more on material and labour costs. There is no calculation under company standards. Craftsmen only calculate the total need for orders which is determined from the raw material and labour costs.

\section{Inheritance of the pattern of distribution activities in terms of distribution channels}

Inheritance in the distribution process is carried out in two ways: direct distribution and distribution through retailers. The successors follow the marketing channel and keep the marketing channel stable. The pioneers provide suggestions on potential market areas and directions on choosing the areas and distributing the product appropriately.Beads MSMEs do not make professional accounting calculations in the inheritance of calculating distribution costs. They are more concerned about the costs of shipping and delivery services. When the craftsmen send the products by themselves, a simple calculation is done by subtracting the value of the products sent by the selling value of the product. The distribution costs should not be more than that. attitude and achievement.

\subsection{Suggestion}

It is suggested to the craftsmen, who are also the owners of beads MSMEs, to create new distribution channels and cooperate with the local government to make beads mandatory accessories for the local community and typical souvenirs of Jombang in institutional or community activities. In addition, the craftsmen should also cooperate with the education authorities regarding the inculcation of local economic potential values and marketing opportunities in the school environment done by school cooperatives.

\section{REFERENCES}

[1] I. Nawawi, 'Globalisasi Ekonomi Bisnis: Studi Arus Nalar Pemikiran Bisnis Kompetitif Islam Kontemporer', Jurnal Maliyah, vol. 3, no. 02, pp. 719-744, 2013.

[2] J. J. W. Tandjung, 'Strategi Perusahaan Lokal Menghadapi Persaingan Masyarakat Ekonomi ASEAN (MEA)', JBT, vol. 1, no. 2, pp. 23-32, 2017, doi: 10.24123/jbt.v1i02.792.

[3] N. H. Faizah and M. S. Suib, 'UMKM dalam Persaingan di Era Globalisasi Ekonomi (Studi di UKM Hunay Probolinggo)', UPAJIWA DEWANTARA, vol. 3, no. 2, pp. 127-135, 2019.

[4] C. Kilic, 'Effects of Globalization on Economic Growth: Panel Data Analysis for Developing Countries', Petroleum-Gas University of Ploiesti Bulletin, Technical Series, vol. 67, no. 1, pp. 1-11, 2015. 
[5] K. E. Bang and T. Markeset, 'Identifying the Drivers of Economic Globalization and the Effects on Companies' Competitive Situation', in Advances in Production Management Systems. Value Networks: Innovation, Technologies, and Management, vol. 384, J. Frick and B. T. Laugen, Eds. Berlin, Heidelberg: Springer, 2012, pp. 233241. doi: 10.1007/978-3-642-33980-6_27.

[6] F. N. Eleanora and A. Sari, 'Distribution of Inheritance Based on The Principle of Justice According to National Law', variajusticia, vol. 15, no. 1, pp. 9-17, Mar. 2019, doi: 10.31603/variajusticia.v15i1.2416.

[7] I. Siregar, A. Arif Nasution, A. Prasetio, and K. Fadillah, 'Analysis of Production Flow Process With Lean Manufacturing Approach', IOP Conf. Ser.: Mater. Sci. Eng., vol. 237, pp. 1-6, 2017, doi: 10.1088/1757-899X/237/1/012002.

[8] M. Kliment, R. Popovič, and J. Janek, 'Analysis of the Production Process in the Selected Company and Proposal a Possible Model Optimization Through PLM Software Module Tecnomatix Plant Simulation', Procedia Engineering, vol. 96, pp. 221-226, 2014, doi: 10.1016/j.proeng.2014.12.147.
[9] A. Jakobczyk, K. Nogaj, J. Diakun, and R. Davidrajuh, 'Production Process Analysis in Conditions of Short-Term Raw Materials Expiration Dates and Long Setup Times Using Simulation Method', in Advances in Manufacturing, A. Hamrol, O. Ciszak, S. Legutko, and M. Jurczyk, Eds. Cham: Springer International Publishing, 2018, pp. 121-130. doi: 10.1007/9783-319-68619-6_12.

[10] T. N. Karundeng, S. L. Mandey, and J. S. B. Sumarauw, 'Analisis Saluran Distribusi Kayu (Studi Kasus di CV. Karya Abadi, Manado)', Jurnal EMBA, vol. 6, no. 3, pp. 1748-1757, 2018. doi.org/10.35794/emba.v6i3.20444

[11] Jainuddin and S. Ernawati,'Pengaruh Promosi dan Saluran Distribusi Terhadap Volume Penjualan Sosis BE MART Cabang Bima', Jurnal Pamator, vol. 13, no. 1, pp. 13-17, April 2020. doi.org/10.21107/pamator.v13i1.6917

[12] N. Diana, S. L. Mandey, and R. J. Jorie, ‘Analyze Influence Of Stategic Product, Price, Promotion, Place To Customers Loyalty (Study Case Radar Manado Newspaper)', Jurnal EMBA, Vol.5 No.2, pp. $2367 \quad$ - 2376, 2017. doi.org/10.35794/emba.v5i2.16638 